\title{
TINJAUAN TEORITIS KEPUTUSAN PEJABAT NEGARA DIKAITKAN DENGAN SISTEM HUKUM NEGARA INDONESIA
}

H Muhamad Rezky Pahlawan MP

Dosen Fakultas Hukum Universitas Pamulang

E-mail : rezkymustikaptra@gmail.com

Received: - /Revised: - /Accepted: Des 2018

\begin{abstract}
Seperti yang kita ketahui sebelumnya bahwa Negara Indonesia adalah Negara hukum, dimana setiap masyarakat yang tinggal di Indonesia hidup dalam kehidupan social yang di atur oleh hukum yang mengikat dan memiliki sanksi. Seluruh warga Negara dijamin kemerdekaannya dan sama kedudukannya di mata hukum, pergerakan dan perputaran roda pemerintahan tentu dijalankan oleh sebuah lembaga kenegaraan dimana dalam sebuah lembaga ada pejabat Negara dan seluruh jajarannya yang menjadikan mereka sebagai Aparatur Sipil Negara.
\end{abstract}

Kata Kunci : Pejabat Negara, Aparatur Sipil Negara, Peradilan Tata Usaha Negara

ABSTRACT

As we know earlier that the State of Indonesia is a State of law, where every society living in Indonesia lives in a social life that is governed by a binding and sanctioned law. All citizens are guaranteed independence and equal position in the eyes of the law, the movement and rotation of the wheels of government must be run by a state institution where in an institution there are State officials and all the staff who make them as civil apparatus State.

Keywords: State Official, State Civil Apparatus, State Administrative Cour

Pendahuluan 
Negara Indonesia adalah Negara hukum yang berdasarkan Pancasila dan Undang undang Dasar Negara Republik Indonesia tahun 1945 bertujuan menata tata kehidupan Negara dan bangsa yang berkehidupan sejahtera, aman, tentram, serta tertib yang menjamin persamaan kedudukan warga masyarakat dalam hukum dan menjamin terpelihara hubungan yang serasi, seimbang, serta selaras antara aparatur dibidang Tata Usaha Negara dengan para warga masyarakatnya ${ }^{1}$. Sehingga dengan mengacu pada undang undang dasar Negara republic Indonesia tahu 1994 atas perubahaan ke empat yang mensematkan Indonesia sebagai Negara hukum dalam passal 1 ayat (3) Indonesia sebagai Negara hukum maka setiap penyelenggaan dan aktifitas kenegaraan yang dijalan kan oleh roda pemerintahan harus lah sesuai dengan aturan aturan dan hukum yang berlaku dan harus sesuai apa yang sudah ditentukan sebelumnya dalam aturan itu sendiri serta tidak bertentangan dengan grand norm atau dasar dasar nilai nilai keadilan keterbukaan dan kemanfaatan bagi seluruh Rakyat Indonesia.

A.V. Dicey mengetengahkan tiga arti dari "the rule of law" yaitu pertama, supremasi hukum (supremacy of law); kedua, persamaan di hadapan hukum (equality before the law); ketiga, terjaminnya hak-hak asasi manusia dalam Konstitusi. Adapun untuk "rechtsstaat" menurut F.J. Stahl mempunyai unsur-unsur : pertama, pengakuan dan perlindungan terhadap hak asasi manusia; kedua; pemisahan dan pembagian kekuasaan negara (trias politica); ketiga, pemerintah berdasarkan undang-undang (wetmatig bestuur); keempat, adanya peradilan administrasi negara (PTUN)2.

\footnotetext{
${ }^{1}$ Baharuddin lopa, Mengenal Peradilan Tata Usaha Negara, Grafika , Jakarta , 1991, hlm 119

${ }^{2}$ Hadjon, Philipus M., 1987, Perlindungan hukum Bagi Rakyat di Indonesia, Sebuah Studi Tentang PrinsipPrinsipnya, Penerapannya oleh Pengadilan Dalam Lingkungan
} 


\section{RECHTSREGEL}

Jurnal Ilmu Hukum Vol 1, No 2 Desember 2018

P-ISSN 2622-6235, E-ISSN 2622-6243,

rjih_fh@unpam.co.id

Landasan mengapa adanya sebuah lembaga yudikatif dalam hal penanganan putusan pejabat Negara yaitu PTUN karena adanya sebuah cita cita dari Negara indoneisa untuk memberi keadilan seadil adilnya bagi masyarakat dan aparatur sipil negaranya.Indonesia sebagai negaa hukum, memiliki system hukum yang dikenal dengan civil law system. Indonesia adalah bekas jajahan belanda sehingga konsekuensinya mendapat warisan system hukum yang juga dipakai di Belanda, namun tidak terlepas dengan perkembangan global sehingga Indonesia menggunakan juga common law system. Kelaziman di Indonesia, hakim satu memakai undang undang sebagai dasar keuputusannya, yang lain memakai hukum adat sebagai dasar putuannya, bahkan juga menggunakan jurisprudensi sebagai dasar putusannya maka sangat perlu mencoba membandingkan paradigm hukum antara civil law system dengan common law system. Hal ini sangat beralasan, mengingat masyarakat Indonesia termasuk tepologi yang sesuai dengan kepraktisan. Sabian Usman menyatakan bahwa system common law yang dianggap praktis dan efisien ketimbang civil law system ${ }^{3}$.

Keniscayaan bagi negara-negara modern untuk menganut paham konstitusionalisme didasarkan pada pemahaman bahwa konstitusi dianggap sebagai perwujudan dari hukum tertinggi yang harus dipatuhi oleh negara dan pejabat-pejabat pemerintah sekalipun, sesuai dengan dalil yang dikemukakan oleh John

Peradilan Umum dan Pembentukan Peradilan Administrasi Negara, Bina Ilmu, Surabaya, 1987, hlm 80

3 Sabian Utsman, Menuju Penegakan Hukum Responsive, Pustaka Pelajar, Yogyakarta, 2008, hlm 71 
Adams "government by law, not by men"4. Sehingga dalam system kenegaraan tentu adanya suatu kekurangan atau kelemahan baik dalam sebuah landasan yuridis maupun implementasi, dan perlu diketahui bahwa suatu keputusan akan dikatakan sah dimata hukum apaila memenuhi unsur Asas Asas Umum Pemerintahan yang Baik atau dsingkat dengan AAUPB. Dan keputusan yang dkeluarkan bersifat konkrit, individual, dan final. Berdasarkan latar belakang tersebut maka penulis tertarik untuk mengangkat tema diatas dengan berjudul 'TINJAUAN TEORITIS KEPUTUSAN PEJABAT NEGARA DIKAITKAN DENGAN SISTEM HUKUM NEGARA INDONESIA DITINJAU DARI UNDANG UNDANG NOMOR 30 TAHUN 2014 TENTANG ADMINISTRASI PEMERINTAHAN DAN UNDANG UNDANG NOMOR 51 TAHUN 2009 TENTANG PERADILAN TATA USAHA NEGARA.

\section{Rumusan Masalah}

Untuk memberikan arah, penulis bermaksud membuat suatu rumusan masalah sesuai dengan arah yang menjadi tujuan dan sasaran penulisan ini. Perumusan masalah menurut istilahnya terdiri atas dua kata yaitu rumusan yang berarti ringkasan atau kependekan, dan masalah yang berarti pernyataan yang menunjukkan jarak antara rencana dengan pelaksanaan, antara harapan dengan kenyataan. Perumusan masalah dalam tulisan ini berisikan bagaimana Implemetasi dan pengaruh keputusan pejabat Negara dikaitkan dengan system hukum Negara Indonesia ditinjau dari undang undang nomor 30 tahun 2014 tentang administrasi pemerintahan dan Undang-

${ }^{4}$ Richard Samuelson "John Adams and the Republic of Law" dalam Bryan-Paul Frost and Jeffrey Sikkenga eds, History of American Political Thought, Lexington Books , Maryland, Lexington Books, 2003, Hlm. 118. 


\section{RECHTSREGEL}

Jurnal Ilmu Hukum Vol 1, No 2 Desember 2018

P-ISSN 2622-6235, E-ISSN 2622-6243,

rjih_fh@unpam.co.id

undang nomer 51 tahun 2009 tentang peradilan tata usaha Negara.

\section{Tujuan dan Kegunaan Penelitian}

Tujuan Penelitian

Dalam penelitin atau tulisan ini diharapkan agar dapat menjawab berbagai permasalahan yang berkaitan keputusan atau beschikking yang dikeluarkan oleh pejabat Negara. Hal ini difokuskan dalam mengkaji aspek Keputusan dan Peradilan Tata Usaha Negara serta mengetahui implemetasi dan pengaruh keputusan pejabat Negara dikaitkan dengan system hukum Negara Indonesia ditinjau dari undang undang nomor 30 tahun 2014 tentang administrasi pemerintahan dan Undang-undang nomer 51 tahun 2009 tentang peradilan tata usaha Negara.

1. Manfaat Penelitian

Kegunaan penelitian atau tulisan ini dibagi menjadi dua untuk memudahkan pembaca dalam memahami manfaat serta harapan penulis dalam menumpahkan pemikiran dalam seuah tulisan ini, yaitu :

a. Kegunaan Teoritis

Secara teoritis penelitian ini diharapkan dapat memberikan sumbangan pemikiran bagi pengembangan ilmu pengetahuan dbidang Hukum Tata Negara khususnya beschikking atau keputusan pejabat Negara dalam sebuah system hukum di Negara Indonesia serta upaya upaya dalam hal melawan sebuah keputusan kepada Peradilan Tata Usaha Negara.

b. Kegunaan Praktis 
(1) Hasil penulisan ini diharapkan dapat berguna sebagai bahan masukan dan saran kepada Pemerintah dan pihak terkait dalam pelaksanaan implementasi sebuah keputusan yang baik dan memenuhi unsur asas asas umum pemerintahan yang baik AAUPB.

(2) Hasil penulisan ini juga di harapkan dapat memberikan informasi bagi pembaca yang ingin mengetahui lebih jauh mengenai pengaruh dari sebuah keputusan dikaitkan dengan sebuah Peradilan Tata Usaha Negara.

\section{Metode Penelitian}

Metode penelitian yang digunakan dalam jurnal ini adalah jenis penelitian hukum normatif. Penelitian hukum normatif adalah penelitian yang dilakukan/berfokus pada norma hukum positif berupa peraturan perundang-undangan. Peraturan perundang-undangan yang digunakan berkaitan dengan pejabat adminsitrasi Negara dan system peradilan tata usaha negara. Sebagaimana dikemukakan oleh Soerjono Soekanto dan Sri Mamudji, penelitian hukum normatif ialah penelitian hukum yang dilakukan dengan cara meneliti bahan pustaka atau data sekunder belaka. Penelitian hukum normative mencakup penelitian terhadap asas-asas hukum, penelitian terhadap sitematika huum, penelitian terhadap taraf sinkronisasi vertical dan horizontal, perbandingan hukum, sejarah hukum ${ }^{5}$

1. Jenis Penelitian

Jenis penelitian ini adalah suatu penelitian hukum normatif yang terfokus dalam norma norma hukum yang berlaku dan pengkajian hukum hukum tesebut dilakukan dengan cara

${ }^{5}$ Soerjono Soekanto dan Sri Mamudji, Penelitian Hukum Normatif: Suatu Tinjauan Singkat,PT Raja Grafindo Persada, Jakarta, 2009, hlm 13-14 


\section{RECHTSREGEL}

Jurnal Ilmu Hukum Vol 1, No 2 Desember 2018

P-ISSN 2622-6235, E-ISSN 2622-6243,

rjih_fh@unpam.co.id

meniliti data data sekunder sebagai data utama dan data primer menjadi sebagi data penunjang.

2. Sumber Data

Data sekunder dalam penelitian ini bersumber dari:

a. Bahan Hukum Primer, yaitu bahan bahan hukum positif yang mengikat dan perundang undangan tersebut terdiri dari Undang Undang Dasar Republik Indonesia tahun 1945, Undang Undang Nomor 30 tahun 2014 tentang Administrasi Pemerintah, Undang Undang Nomor 51 tahun 2009 tentang Peradilan Tata Usaha Negara.

b. Bahan Hukum Sekunder, yaitu merupakan suatu bahan bahan yang digunakan untuk memberikan penjelasan mengenai bahan hukum primer dan terdiri dari literature-literatur yang berisi tentang pendapat pendapat hukum.

\section{Pembahasan}

\section{Konsep Negara Hukum}

Dalam undang undang dasar Negara republik Indonesia tahun 1994 atas perubahaan ke empat yang mensematkan Indonesia sebagai Negara hukum dalam passal 1 ayat (3) Indonesia sebagai Negara hukum maka setiap penyelenggaan dan aktifitas kenegaraan yang dijalan kan oleh roda pemerintahan harus lah sesuai dengan aturan aturan dan hukum yang berlaku dan harus sesuai apa yang sudah ditentukan sebelumnya dalam aturan itu sendiri serta tidak bertentangan dengan grand norm atau dasar dasar nilai nilai keadilan keterbukaan dan kemanfaatan bagi seluruh Rakyat Indonesia. 
Garry F Bell dalam buku nya The New Indonesia laws Relating to Regional Autonomiy Good Intens, confusing laws yang dikutip oleh Denny Indrayana bahwa dalam konteks Negara hukum Indonesia mendekati konsep continental (rechsstaat). MMemperhatikan konsep ngara hukum oleh Ismail sunny dalam bukunya Titik Triwulan Tutik pokok pokok Tata Negara mencatat ada empat syarat Negara hukum yaitu6 :

a. Hak Asasi Manusia

b. Pembagian Kekuasaan

c. Pemerintahan berdasarkan Undang-undang

d. Peradilan Administrasi

Dengan demikian jelas lah bahwa Indonesia merupakan Negara hukum yang berlandaskan pancasila yang mengedepankan norma norma hukum mengingat Indonesia menganut paham eropa continental yang berlandaskan asas rechstaat atau Negara hukum. Melihat dari ciri ciri Negara Indonesia menjadi Negara berkembang yang menganut system eropa continental atau biasa dikenal istilah civil law. Undangundang dasar Negara republic Indonesia tahun 1945 menjadi landasan atau dasar dalam pembentukan undang-undang, dikatakan demikian karena Undang-undang dasar tahun 1945 menjadi konstitusional Negara atau Groundnorm adapun konsep suatu Negara hukum yang dikemukakan oleh Phillip, Jackson, Leopold adalah sebagai berikut7 :

" a fully developed modern statetis expected to deal with vast mass of social problem, either by direct activity or by supervision or regulation. In order to carry out these functions, the state must have a agents or organs through which operate.

6 Titik Triwulan Tutik, Pokok-pokok Hukum Tata Negara, Pustaka Publisher, Jakarta, 2006, hlm 119

${ }^{7}$ Prof. Dr Jimly Asshiddiqie, SH, Pengantar Ilmu Hukum Tata Negara, PT Raja Grafindo Persada, Jakarta, 2015, hlm 10 
The appointment or establishment of these agents organs, the general nature of their function and powers, their relations inter and between them and private citizen, from a large part of the constitution of a state".

Dari apa yang di sampaikan pakar dari inggris tersebut, ada juga pendapat yang dikemukakan oleh Hans Kelsen ini bisa disampaikan kembali bahwa Negara sebagai penjelmaan tata hukum nasional yang dapat dilihat dari hukum yang dihasilkannya. Maka hukum yang dikeluarkan oleh Negara adalah berdaulat, dimana hukum dijunjung tinggi masyarakat Negara. Proses menjungjung tinggi hukum yang dikeluarkan Negara inilah yang kemudian yang dikenal sebagai salah satu ciri Negara hukum ${ }^{8}$.

Jika Negara hukum yang berlandaskan undangn undang tentu dalam system ketataNegaraan Indonesia kedudukan tertinggi yang menjadi dasar dasar pembentukan undang undang adalah Pancasila dan konstitusi yang menjadi dasar landasan utama, sehingga tidak boleh undang-undang dibawahnya yang bertentangan dengan konstitusi Negara Indonesia. Paham konstitusionalisme pada hakikatnya berbasis pokok pada adanya kesepakatan umum (consensus) di antara mayoritas rakyat mengenai bangunan yang diidealkan berkenaan dengan negara. Pernyataan ini didasarkan pada kenyataan di mana organisasi negara itu diperlukan oleh warga negara agar kepentingan mereka bersama dapat dilindungi atau dipromosikan melalui pembentukan dari apa yang dinamakan negara, sebagaimana yang ditegaskan oleh William George Andrews bahwa "The

${ }^{8}$ Prof. Drs. C.S.T. Kansil, SH, dan Christine S.T. Kansil, SH, MH, Perbandingan Hukum Administrasi Negara, PT Rineka Cipta, Jakarta, 2010, hlm 7 
members of a political community have, definition, common interests which they seek to promote or protect through the creation and use of the compulsory political mechanisms we call the State"y Jadi kata kuncinya di sini adalah konsensus atau general agreement. Lebih lanjut jelaskannya bahwa konsensus atau general agreement itu meliputi : "(a) the general goals of society or general acceptance of the same philosophy of government; (b) the rule of law the basis of government; and (c) the reform of institutiions and procedures ${ }^{10}$.

Adapun Negara hukum yang baik tentu di dasari dan digeraki oleh roda pemerintahan yang baik pula, dimana asas asas pemerintahan yang baik adalah teridiri dari :

a. kepastian hukum;

b. kemanfaatan;

c. ketidakberpihakan;

d. kecermatan;

e. tidak menyalahgunakan kewenangan;

f. keterbukaan;

g. kepentingan umum; dan

h. pelayanan yang baik.

Asas-asas umum lainnya di luar AUPB sebagaimana dimaksud dapat diterapkan sepanjang dijadikan dasar penilaian hakim yang tertuang dalam putusan Pengadilan yang berkekuatan hukum tetap. Dengan demikian tentu ada asas asas umum pemerintahan yang baik yang harus dijaga integritasnya dan terimplementasi agar terciptanya konsep Negara hukum yang baik dan sesuai dengan apa yang di cita citakan oleh sebuah konstitusi.

${ }^{9}$ William George Andrews, Constitutions and Constitutionalism, $3^{\text {rd }}$ ed., Van Nostrand Company, New Jersey, 1968, HIm. 9.

10 Ibid, hlm 12-13 


\section{Pengertian Keputusan (Beschikking) Terhadap Wewenang}

\section{Pejabat Negara}

Pejabat Negara adalah salah satu alat kelengkapan Negara menjalankan roda pemerintahan untuk menciptakan keselarasan dan administrasi pemerintahan dalam hal melayani masyarakat warga Negara Indonesia, dalam sebuah pergerakan roda pemerintahan pejabat Negara mengeluarkan sebuah putusan perdata yang bersifat privat dan hanya berlaku bagi sseseorang yang tercantum dalam keputusan. Keputusan pejabat Negara disebut beschikking yang artinya adalah salah satu bentuk kegiatan pemerintah dalam menjalankan peranannya yang tergolong dalam perbuatan hukum pemerintah (Rechtshandelingen). Arti bahasa atau bahasa asal dari beschikking berasal dari Belanda,acte administrative (Prancis), verwaltunngsakt (Jerman). Dimana menurut Utrecht memiliki pengertian yang adalah suatu perbuatan hukum publik yang bersegi satu yang dilakukan oleh alat alat pemerintahan berdasarkan suatu kekuasaan istimewa, atau merujuk pada pengertian menurut Van Der Pot didefiniskikan sebagai perbuatan hukum yang dilakukan alat alat pemerintahan, pernyataan pernyataan kehendak alat alat pemerintahan itu dalam menyelenggarakan hal hal istimewa dengan maksud mengadakan perubahan dalam lapangan perhubungan perhubungan hukum. Dalam sumber lain beschiking diartikan sebagai suatu keputusan yang diterbitkan oleh pejabat administrasi yang bersifat konkret dan khusus atau keputusan dalam bidang administrasi negara dilakukan oleh pejabat atau 
badan pemerintah yang berwenang dan berwajib khusus untuk itu.

Keputusan tata usaha negara (beschikking) oleh Utrecht disebut sebagai 'ketetapan', sedangkan Prajudi Atmosudirdjo menyebutnya dengan 'penetapan' .Utrecht, PRINS, dan Van der Pot, juga menjelaskan bahwa beschikking merupakan perbuatan hukum publik yang bersegi satu atau perbuatan sepihak dari pemerintah dan bukan merupakan hasil persetujuan dua belah pihak

Beschiking Menurut UU No.5 Tahun 1986 jo. UU No.9 Tahun 2004

Undang-undang No. 5 Tahun 1986 tentang Peradilan Tata Usaha Negara menyebutkan bahwa Keputusan Tata Usaha Negara adalah suatu penetapan tertulis yang dikeluarkan oleh Badan atau Pejabat Tata Usaha Negara yang berisi tindakan hukum Tata Usaha Negara yang berdasarkan peraturan perundangundangan yang berlaku, yang bersifat konkret, individual, dan final, yang menimbulkan akibat hukum bagi seseorang atau badan hukum perdata. Dari definisi menurut UU Nomor 5 Tahun 1986 tersebut dapat dirumuskan unsur-unsur keputusan sebagai berikut ${ }^{11}$, yaitu :

a. penetapan tersebut tertulis dan dikeluarkan oleh badan atau Pejabat Tata Usaha Negara,

b. berisi tindakan hukum dalam bidang Tata Usaha Negara,

c. berdasarkan peraturan perundang-undangan yang berlaku

d. bersifat konkrit, individual, dan final

e. serta menimbulkan akibat hukum bagi seseorang atau badan hukum perdata. 


\section{RECHTSREGEL}

Jurnal Ilmu Hukum Vol 1, No 2 Desember 2018

P-ISSN 2622-6235, E-ISSN 2622-6243,

rjih_fh@unpam.co.id

Keputusan merupakan penetapan tertulis sebagai wadah atau perwujudan dari beragai bentuk penerapan norma norma hukum secara tertulis, keputusan adalah tindakan tertulis yang dikeluarkan oleh pejabat berwenang bersifat seblah pihak dengan tanpa meminta persetujuan dari pihak yang dikenai keputusan, sedangkan ketetapan adalah bentuk tindakan tertulis yang dikeluarkan oleh pejabat berwenang yang dilakukan oleh badan pemerintahan.

Juga dalam Undang-undang nomor 30 tahun 2014 tentang Administrasi Pemerintahan Syarat Sahnya Sebuah Keputusan adalah :

Pasal 52 ayat (1) Syarat sahnya Keputusan meliputi:

a. ditetapkan oleh pejabat yang berwenang;

b. dibuat sesuai prosedur; dan

c. substansi yang sesuai dengan objek Keputusan.

Ayat (2) Sahnya Keputusan sebagaimana dimaksud pada ayat (1) didasarkan pada ketentuan peraturan perundangundangan dan AUPB.

Lebih lanjut dalam pasal 70 tentang pembatalan atau tidak sah nya sebuah Keputusan.

(1) Keputusan dan/atau Tindakan tidak sah apabila:

a. dibuat oleh Badan dan/atau Pejabat Pemerintahan yang tidak berwenang;

b. dibuat oleh Badan dan/atau Pejabat Pemerintahan yang melampaui kewenangannya; dan/atau

c. dibuat oleh Badan dan/atau Pejabat Pemerintahan yang bertindak sewenang-wenang. 
(2) Akibat hukum Keputusan dan/atau Tindakan sebagaimana dimaksud pada ayat (1) menjadi:

a. tidak mengikat sejak Keputusan dan/atau Tindakan tersebut ditetapkan

b. segala akibat hukum yang ditimbulkan dianggap tidak pernah ada.

(3) Dalam hal Keputusan yang mengakibatkan pembayaran dari uang negara dinyatakan tidak sah, Badan dan/atau Pejabat Pemerintahan wajib mengembalikan uang ke kas negara.

Paragraf 2

Akibat Hukum Keputusan dan/atau Tindakan yang Dapat Dibatalkan

Pasal 71

(1) Keputusan dan/atau Tindakan dapat dibatalkan apabila:

a. terdapat kesalahan prosedur; atau

b. terdapat kesalahan substansi.

(2) Akibat hukum Keputusan dan/atau Tindakan sebagaimana dimaksud pada ayat (1):

a. tidak mengikat sejak saat dibatalkan atau tetap sah sampai adanya pembatalan; dan

b. berakhir setelah ada pembatalan.

(3) Keputusan pembatalan dilakukan oleh Pejabat Pemerintahan dan/atau Atasan Pejabat dengan menetapkan dan/atau melakukan Keputusan baru dan/atau Tindakan Pejabat Pemerintahan atau berdasarkan perintah Pengadilan.

(4) Penetapan Keputusan baru sebagaimana dimaksud pada ayat (3) menjadi kewajiban Pejabat Pemerintahan.

(5) Kerugian yang timbul akibat Keputusan dan/atau Tindakan yang dibatalkan menjadi tanggung jawab Badan dan/atau Pejabat Pemerintahan.

Pasal 72 


\section{RECHTSREGEL}

Jurnal Ilmu Hukum Vol 1, No 2 Desember 2018

P-ISSN 2622-6235, E-ISSN 2622-6243,

rjih_fh@unpam.co.id

(1) Badan dan/atau Pejabat Pemerintahan wajib melaksanakan Keputusan dan/atau Tindakan yang sah dan Keputusan yang telah dinyatakan tidak sah atau dibatalkan oleh Pengadilan atau pejabat yang bersangkutan atau atasan yang bersangkutan.

(2) Ketentuan mengenai tata cara pengembalian sebagaimana dimaksud dalam Pasal 70 ayat (3) dan tanggung jawab Badan dan/atau Pejabat Pemerintahan akibat kerugian yang ditimbulkan dari Keputusan dan/atau Tindakan sebagaimana dimaksud dalam Pasal 71 ayat (5) diatur dalam Peraturan Pemerintah $^{12}$.

Sehingga dalam Undang-undang nomor 30 tahun 2014 tentang adminstrasi pemerintahan sudah sangat jelas hal hal yang berkaitan dengan syarat sah dan tidak sah nya sebuah keputusan atau Beschikking.

\section{Kedudukan Keputusan (Beschikking) Dikaitkan dengan Peradilan Tata Usaha Negara (PTUN)}

Penyelenggaraan putusan suatu pemerintahan dilaksanakan dan dikeluarkan oleh pejabat Negara dan bersifat hukum public bukan hukum privat dikarenakan, karena wewenang untuk berbuat sesuatu tentu berdasarkan peraturan yang sudah ada dalama autran hukum Tata Usaha Negara sehingga dasar dari keputusan tersebut tentu adalah peraturan, setiap pejabat Negara tidak bias untuk mengeluarkan suatu keputusan tanpa didasari dengan aturan aturan yang sudah ada, apabila melanggar tentu adanya sebuah tindakan yang tidak benar bias masuk kedalam katagori korupsi seperti apa yang

${ }^{12}$ Undang-undang Nomor 30 tahun 2014 tentang Adminitrasi Pemerintahan 
sudah di jelaskan dalam Undang-undang nomor 20 tahun 2001 tentang Tindak Pidana Korupsi.

Keputusan Tata Usaha Negara adalah merupakan penetapan tertulis yang dikeluarkan oleh Badan atau Pejabat Tata Usaha Negara berdasarkan atas peraturan perundang undangan yang bersifat konkrit, individual dan final ${ }^{13}$. Sehingga setiap keputusan tercatatkan dan teregistrasi dengan sah dalam catatan Negara pada setiap masing masing Badan atau Lembaga, tentu keputusan yang dikeluarkan akan menimbulkan pro dan kontra mengingat keputusan bersifat hukum public dan tidak perlu diskusi atau peretujuan dari yang diberikan keputusan tersebut, ada sebuah lembaga peradilan yang khusus berfungsi dalam menngani konflik wewenang dalam sebuah keputusan yang di keluarkan oleh pejabat Negara yang bernama Peradilan Tata Usaha Negara dimana ini semua di atur dalam UUD 1945 dapat ditemukan dalam pasal 24 yang menyebutkan:

(1) Kekuasaan kehakiman dilakukan oleh sebuah Mahkamah Agung dan lain-lain badan kehakiman menurut undang-undang. (2) Susunan dan kekuasaan badan-badan kehakiman itu diatur dengan undang-undang.

Sebagai pelaksanaan Pasal 24 UUD 1945, dikeluarkanlah Undang-undang Nomor 14 Tahun Tahun 1970 tentang Ketentuan Pokok Kekuasaan Kehakiman. Dalam Pasal 10 ayat (1) disebutkan bahwa kekuasaan kehakiman dilakukan oleh pengadilan dalam lingkungan:

a. Peradilan Umum;

b. Peradilan Agama;

c. Peradilan Militer;

d. Peradilan Tata Usaha Negara.

${ }^{13}$ Soegijatno Tjakra Negara, Hukum Acara Peradilan Tata Usaha Negara, Sinar Grafika, Jakarta, 1994, hlm 4. 
Sehingga Peradilan Tata Usaha Negara masuk kedalam peradilan khusus yang menangani kasus-kasus yang berkaitan dengan sebuah konflik wewenang tergadap keputusan pejabat Tata Usaha Negara. Fungsi hukum ialah menegakkan kebenaran untuk mencapai keadilan. Keadilan adalah merupakan hal yang pokok bagi manusiadalam hidup bermasyarakat, maka dibutuhkan adanya lembaga-lembaga yang bertugas menyelenggarakan keadilan ini. Keadilan ini dituntutkan untuk semua hubungan masyarakat, hubungan-hubungan yang diadakan oleh manusia dengan menusia lainnya, oleh karena itu berbicara tentang keadilan meliputi segala kehidupan manusia dalam hubungannya dengan manusia lain.

Keadilan ini erat hubungannya dengan kebenaran, karena sesuatu yang tidak benar tidaklah mungkin adil. Sesuatu itu benar menurut norma-norma yang berlaku akan tercapailah keadilan itu. Juniarto, SH mengemukakan ada 4 macam kebenaran untuk mencapai keadilan ${ }^{14}$.

1) Kebenaran di dalam menentukan norma-norma hukum yang berlaku agar sesuai dengan rasa kebenaran yang hidup dalam masyarakat.

2) Kebenaran berupa tindakan-tindakan dari setiap anggota masyarakat dalam melakukan hubungan agar sesuai dengan norma-norma hukumya berlaku.

3) Kebenaran dalam mengetahui fakata-fakta tentang hubunganhubungan yang sesungguhnya terjadi sehingga tidak ada 
penambahan atau pengurangan maupun penggelapan daripadanya.

4) Kebenaran di dalam memberikan penilaian terhadap faktafaktanya terhdap norma-norma hukum yang berlaku.

Kepada lembaga-lembaga yang bertugas untuk menetapkan keadilannya atau dengan perkataan lain bertugas memberi kontrol, meminta pertanggungjawaban dan memberikan sanksi-sanksinya, maka tindakan pertama yang harus diperhatikan ialah mencari kebenaran tentang fakta-fakta. Peradilan Tata Usaha Negara adalah salah satu lembaga yang bertugas menyelenggarakan keadilan ini juga harus memperhatikan kebenaran-kebenaran tersebut untuk mencapai keadilan. Demikian pula para anggota yang duduk dalam lembaga ini harus mempunyai keadilan khusu untuk itu dan terutama sekali mempunyai pengetahuan hukum yang cukup luas. Berdasarkan tulisan tersebut diatas, yang dapat menjadi objek gugatan hanyalah tindakan hukum publik- pemerintah yang berupa beschikking, (ketetapan), sebagai instrumen hukum publik yang dlgunakan oleh pemerintah yang, memiliki sifat sepihak (eenjizdige) dan ditujukan untuk hal yang bersifat individual. Instrumen hukum publik pemerintah yang tidak memiliki sifat sepihak dan individual, dengan sendirinya tidak dapat disebut sebagai ketetapan dan tidak dapat menjadi objek sengketa tata usaha negara. Hal ini berarti bahwa rumusan tentang perkecualian KTUN yang tercantum dalam Pasai 2 UU PTUN rnenjadi tidak diperiukan, karena KTUN yang merupakan perbuatan perdata. merupakan ,pengaturan yang bersifat umum, dan lain-lain dengan sendirinya tidak dapat disebut ketetapan.

Dengan demikian apabila putusan sudah putus pada suatu perkara snegketa KPTUN yang disidangkan oleh Peradilan Tata Usaha Negara maka membebankan kewajiban yang harus 


\section{RECHTSREGEL}

Jurnal Ilmu Hukum Vol 1, No 2 Desember 2018

P-ISSN 2622-6235, E-ISSN 2622-6243,

dipikul oleh tergugat. Sebagai suatu kewajiban. isi putusan haruslah dipenuhi dan dilaksanakan oleh tergugat dan pelaksanaan putusan PTUN baru dapat dilaksanakan dan dilakukan oleh tergugat apabila hanya dapat dilakukan terhadap putusan yang telah memperoleh kekuatan hukum tetap (kracht van gewijsde), sebagaimana ditentukan dalam Pasal 115 UU PTUN; "hanya putusan Pengadilan yang telah memperoleh kekuatan hukum tetap yang dapat dilaksanakan". Beradasrkan pasal di atas yg disbeutkan maka dengan sendirinya menolak pelaksanaan putusan yang belum memperoleh kekuataan hukum tetap (uivoorbaar bij vooraad).

Dalam pelaksanaan putusan PTUN terdapat dua jenis eksekusi yaltu; eksekusi otomatis dan eksekusi hirarkis. Eksekusi otomatis terdapat dalam Pasal 116 ayat (2) yaitu; "Dalam hal empat bulan setelah putusan pengadilan yang telah memperoleh kekuatan hukum yang tetap sebagaimana dimaksud dalam ayat (1) dikirimkan tergugat tidak melaksanakan kewajibannya sebagaimana dimaksud dalam Pasal 97 ayat (9) huruf a, maka KTUN yang disengketakan itu tidak mempunyai kekuatan hukum", sedangkan e/fsekus/h/rarif/sterdapatdalam Pasal116 ayat (4), (5), dan (6) yang berbunyi sebagal berikut: (4) Jika tergugat masih tidak mau melaksanakannya, ketua pengadilan mengajukan hal ini kepada instansi atasannya menurut jenjang jabatan. (5) Instansi atasan -sebagaimana dimaksud dalam ayat(4), dalam waktu dua bulan setelah menerima pemberitahuan dari ketua pengadilan hams sudah memerintahkan pejabat sebagaimana dimaksud dalam ayat (3) melaksaniakan putusan pengadilan tersebut. (6) Dalam hal instansi atasan sebagaimana 
dimaksud dalam ayat (4). tidak mengindahkan ketentuan sebagaimana dimaksud dalam ayat (5), maka ketua pengadilan mengajukan hal Ini kepada presiden sebagal pemegang kekuasaan pemerintah tertinggi untuk memerintahkan pejabat tersebut melaksanakan putusan pengadilan tersebut.

Adapun kendala yang sering muncul di permukaan adalah dimana adanya berkenaan dengan pelaksanaan, mengingat putusan dari seorang hakim yang memberikan tetapan hukum lebih banyaknya pejabat yang kalah berperkara, namun di satu sisi tidak mau melaksanakan putusan PTUN meskipun sudah diberi peringatan. Menurut Benjamin Mangkudilaga, ada sejumlah pejabat yang tidak mematuhi putusan pengadilan, perbandingannya sekitar 65 persen yang melaksanakan dan 35 persen membandel, sehingga dengand demikian Terhadap ketidakpatuhan pejabat Ini muncul sejumlah usulan. Benjamin mengusulkan agar pejabat yang membandel dikenakan pidana atau diumumkan secara terbuka, sedang Abdul Hakim Garuda Nusantara mengusulkan agar pejabat yang membandel tersebut dikatagorikan melakukan contempt of court. Menurutnya contempt of court tidak hanya terbatas pada pelecehan di depan sidang, tetapi juga tindakan yang melecehkan pengadilan ${ }^{15}$. Dengan adanya sanksi sanksi maka mau tidak mau pejabat Negara yang kalah dalam sebuah peradilan tata usaha Negara karena putusan nya yg di batalkan atau dikalahkan PTUN terhadap tergugat akan mampu dan mau tidak mau harus melaksanan. Terlepas dari kendala-kendala teoritisdan praktis dalam pelaksanaan putusan pengadilan tersebut, satu hal yang perlu diperhatikan adalah harus memuat ketentuan sanksi yang tegas dalam undang-undang PTUN. Salah satu kekurangan

${ }^{15}$ Farum Keadilan Nomor 22 Tahun II. 17 februari 1994,Hlm. 24 


\section{RECHTSREGEL}

Jurnal Ilmu Hukum Vol 1, No 2 Desember 2018

P-ISSN 2622-6235, E-ISSN 2622-6243,

rjih_fh@unpam.co.id

mendasar dalam pelaksanaan putusan adalah karena UU PTUN tidak rnemuat tentang pemberian sanksi bagi tergugat yang kalah berperkara. Memuat ketentuan sanksi merupakan hal penting dalam peraturan perundangundangan, karena normativisasi hukum tidak cukup hanya sekadar memuat perintah dan iarangan; Dibalik larangan harus ada ketentuan sanksi atas ketidakpatuhan. Sanksi hukum sampai saat ini masih merupakan alat yang paling ampuh untuk menjaga wibawa hukum atau dengan kata lain agar setiap orang patuh terhadap hukum ${ }^{16}$.

Dengan demikian bahwa kekalahan dan kemenangan yang terjadi dalam sebuah peradilan tentu harus di sikapi dengan dewasa oleh setiap para penggugat dan tergugat, karena dengan adanya putusan atau vonis dari hakim yang bersifat asas res yudicata pro veritate habetur dimana setiap putusan hakim harus dianggap benar sekalipun mendapatkan keterangan dari saksi saksi yang salah. Perlu adanya sebuah kedewasaan dari segala pihak dalam menciptakan Negara Indonesia yang berbangsa dan bernegara dalam tatanan yang bermartabat, dan perlu adanya contoh teladan dari para aparatur khususnya pejabat Tata Usaha Negara dalam menjalankan tugas tugas dan tindakan kesengketaan dalam sebuah peradilan yang menghormati secara menyeluruh atas segala hal hal yang terkait.

\section{Penutup}

Kesimpulan

${ }^{16}$ Zairin Harahap, Hukum Acara Peradulan Tata Usaha Negara, Rajawali, Jakarta, 1997, hlm 147. 
Negara Indonesia adalah Negara hukum yang seperti sudah tertuang dalam Undang-undang Dasar Negara Republik Indonesia tahun 1945 pada pasal 1 ayat (3) oleh karenanya segala aspek Implementasi kehidupan bermasyarakat, berbangsa, dan bernegara harus lah betul dalam berlandaskan hukum yang berlaku dengan bertujuan menciptakan rasa aman, tertib, tentram, dan berkeadilan didalam kehidupan berbangsa dan bernegara. Kedudukan suatu Keputusan Tata Usaha Negara (KTUN) dalam system hukum di Indonesia adalah bersifat keputusan atau Beschikking yang mana bersifat final, konkrit, dan individual namun bukan merupakan hukum perdata dikarenakan dasar dari sebuah putusan tetap mengacu pada peraturan yang bersifat public. Dalam pelaksanaan sebuah keputusan tidak boleh melanggar dari ketentuan perundang undangan yang berlaku agar keputusan tersebut tidak berujung pada persengketaan yang di selenggarakan oleh Peradilan Tata Usaha Negara (PTUN).

\section{Saran}

Pejabat Tata Usaha Negara harus selalu memberikan penyuluhan dan seminar mengenai konsep Negara hukum kepada setiap jajaran dan instansi secara periodik, agar terciptanya sebuah kesadaran hukum dan menghindarkan dari sebuah pelanggaran atau kesewenangan dalam mengeluarkan sebuah keputusan tata usaha Negara (KTUN). Anggota legislative perlu menciptakan Undang Undang peradilan Tata Usaha Negara yang memuat tentang perlindungan dan jaminan agar setiap putusan atau vonis hakim PTUN dapat tereksekusi dengan baik, dan perlu adanya sinergitas dan kerja sama antara Peradilan dan Aparat penegak hukum sehingga landasan hukum formil dan hukum matril nya berjalan selaras dalam sebuah sinergitas dan integritas yang tinggi. 


\section{RECHTSREGEL}

Jurnal Ilmu Hukum Vol 1, No 2 Desember 2018

P-ISSN 2622-6235, E-ISSN 2622-6243,

rjih_fh@unpam.co.id

\section{Daftar Pustaka}

\section{Buku-buku}

Baharuddin lopa, Mengenal Peradilan Tata Usaha Negara, Grafika , Jakarta , 1991.

Hadjon, Philipus M., 1987, Perlindungan hukum Bagi Rakyat di Indonesia, Sebuah Studi Tentang PrinsipPrinsipnya, Penerapannya oleh Pengadilan Dalam Lingkungan Peradilan Umum dan Pembentukan Peradilan Administrasi Negara, Bina Ilmu, Surabaya, 1987.

Sabian Utsman, Menuju Penegakan Hukum Responsive, Pustaka Pelajar, Yogyakarta, 2008.

Richard Samuelson "John Adams and the Republic of Law" dalam Bryan-Paul Frost and Jeffrey Sikkenga eds, History of American Political Thought, Lexington Books , Maryland, Lexington Books, 2003.

Soerjono Soekanto dan Sri Mamudji, Penelitian Hukum Normatif: Suatu Tinjauan Singkat,PT Raja Grafindo Persada, Jakarta, 2009 .

Titik Triwulan Tutik, Pokok-pokok Hukum Tata Negara, Pustaka Publisher, Jakarta, 2006.

Prof. Dr Jimly Asshiddiqie, SH, Pengantar Ilmu Hukum Tata Negara, PT Raja Grafindo Persada, Jakarta, 2015.

Prof. Drs. C.S.T. Kansil, SH, dan Christine S.T. Kansil , SH, MH, Perbandingan Hukum Administrasi Negara, PT Rineka Cipta, Jakarta, 2010. 
William George Andrews, Constitutions and Constitutionalism, $3^{\text {rd }}$ ed., Van Nostrand Company, New Jersey, 1968.

Soegijatno Tjakra Negara, Hukum Acara Peradilan Tata Usaha Negara, Sinar Grafika, Jakarta, 1994.

Farum Keadilan Nomor 22 Tahun II. 17 februari 1994.

Zairin Harahap, Hukum Acara Peradulan Tata Usaha Negara, Rajawali, Jakarta, 1997.

\section{Website Internet}

http://belajarhukum27.blogspot.co.id/2014/12/makalah-peradilantata-usaha-negara.html

https://anjarnawanyep.wordpress.com/beschikking-keputusanatau-penetapan/

\section{Perundang Undangan}

Undang-undang nomor 30 tahun 2014 tentang Administrasi Pemerintahan

Undang-undang nomor 51 taun 2009 tentang Peradilan Tata Usaha Negara perubahan atas UU No.9 Tahun 2004 dan UU Nomor 5 Tahun 1986

Undang-undang nomor 20 tahun 2001 tentang Tindak Pidana Korupsi 